\title{
KINERJA TERMAL RUMAH NIANG DI DATARAN TINGGI TROPIS LEMBAB DI DISTRIK MANGGARAI
}

\author{
P. Jhon Alfred D.D ${ }^{1}$, I Gusti Ngurah Antaryama ${ }^{2}$, Sri Nastiti N.E \\ ${ }^{1 .}$ Program Studi Arsitektur, Universitas Flores, Ende \\ 2. Jurusan Arsitektur, Institut Teknologi Sepuluh Nopember (ITS), Surabaya \\ 3. Jurusan Arsitektur, Institut Teknologi Sepuluh Nopember (ITS), Surabaya \\ ff3redo@gmail.com
}

\begin{abstract}
Abstrak
Rumah Niang merupakan salah satu dari sepuluh ragam Arsitektur Tradisional di Provinsi Nusa Tenggara Timur yang berada di dataran tinggi Kabupaten Manggarai (800 - 1200 dpl) dengan kekhasan yang dimilikinya yaitu denah yang berbentuk lingkaran dan atap berbentuk kerucut. Rumah Niang tumbuh dari rakyat dengan segala macam tradisi serta memanfaatkan berbagai potensi-potensi lokal seperti material, teknologi dan pengetahuan yang ada. Namun potensipotensi lokal seperti penggunaan material lightweight tersebut menimbulkan permasalahan di daerah dataran tinggi yang cenderung dingin karena sifat termal dari material lightweight mudah lepas dan mengalir keluar sehingga dapat berpotensi menciptakan kondisi underheating dan mempengaruhi kondisi kenyamanan dalam bangunan. Penelitian ini bertujuan untuk mengevaluasi pengaruh desain rumah Niang dalam merespon kondisi termal di dataran tinggi dan menganalisis perilaku material dari elemen desain yang berpengaruh terhadap kinerja termal rumah Niang. Penelitian dilakukan dengan metode observasi dan simulasi dengan bantuan software ARCHIPAK versi 5.0. Hasil akhir dalam penelitian ini menunjukkan bahwa desain rumah Niang belum dapat memberikan kenyamanan termal yang memadai terutama pada malam hingga pagi hari, di mana kondisi bangunan cenderung mengalami underheating dalam periode yang cukup lama. Dari simulasi juga dapat diketahui bahwa lantai dan atap merupakan elemen yang paling kritis terhadap pelepasan panas.
\end{abstract}

Kata kunci: rumah Niang, kondisi termal, dataran tinggi

\begin{abstract}
Title: The Performance of Niang House in the Tropical Highland of Manggarai District

Niang home is one of the ten varieties of Traditional Architecture in East Nusa Tenggara Province located in the highlands of Manggarai district (800 - 1200 meters above sea level) with its peculiarities, namely the circular floor plan and a conical roof. Niang home is growth by people with all kinds of traditions and utilize a variety of local potentials such as materials, technology and knowledge. But local potentials such as the use of lightweight materials such problems occur in upland areas that tend to be cold because the thermal properties of lightweight material is loose and flowing out so that it can potentially create underheating and conditions affecting comfort conditions in buildings. This study aimed to evaluate the effect of house design of Niang in response to thermal conditions in the highlands and analyze the behaviour of the material of the design elements that affect the thermal performance of the house of Niang. The study was conducted by the method of observation and simulation with the help of software ARCHIPAK version 5.0. The final results of this study indicate that the design of Niang house can not provide adequate thermal comfort, especially at night until morning, where the condition of the buildings tend to underheating in considerable period of time. From the simulation can also be seen that the floor and the roof is the most critical element of the heat release.
\end{abstract}

Keywords: Niang house, thermal conditions, highland 


\section{Pendahuluan}

Arsitektur tradisional merupakan hasil dari pengalaman klimatik selama bertahun-tahun dan banyak membuktikan kemampuannya dalam merespon iklim setempat dengan baik. Namun prinsip-prinsip dari rumah tradisional saat ini jarang dipertimbangkan dalam desain rumah masa kini. Banyak juga dijumpai rumah-rumah tradisional di Indonesia yang mengalami pergeseran makna/fungsi atau perubahan bentuk yang disebabkan oleh modernisasi.

Rumah Niang merupakan bangunan tradisional yang ada di dataran tinggi Kabupaten Manggarai (800 hingga 1200 diatas permukaan laut) dan merupakan salah satu dari sepuluh ragam arsitektur tradisional di Provinsi Nusa Tenggara Timur (Damayanti dan Suprijanto, 2009). Rumah Niang memiliki kekhasan tersendiri dan berbeda dengan rumah-rumah tradisional lainnya yang ada di Indonesia karena denahnya berbentuk lingkaran dengan atap berbentuk kerucut. Rumah Niang masih dapat ditemui di beberapa lokasi di Kabupaten Manggarai, seperti di desa Todo, Wae Rebo (masih sesuai dengan karakter fisik aslinya) dan di kampung Ruteng Pu'u, Kumba, Cibal, Narang, Pagal, (karakter fisik yang mengalami perubahan bentuk).

Kondisi lingkungan di wilayah ini terbilang cukup dingin dengan suhu udara berkisar $15^{\circ} \mathrm{C}$ sampai dengan $25^{\circ} \mathrm{C}$. Pada musim kemarau terutama pada bulan Juli sampai Agustus adalah bulan terdingin, dimana suhu udara dapat mencapai $12^{\circ} \mathrm{C}$ pada pagi hari. Dengan kondisi lingkungan yang cukup dingin maka dapat menimbulkan masalah dan berpotensi untuk menciptakan kondisi underheating pada malam hari sehingga mempengaruhi kondisi kenyamanan dalam bangunan. Desain dari rumah Niang berbentuk single layer dan menggunakan material konstruksi ringan (lightweight structure) ini dapat menyebabkan panas di dalam bangunan tidak dapat tersimpan lebih lama pada struktur bangunan sehingga mudah dilepaskan dan mengalir keluar.

Tujuan dalam penelitian ini adalah mengevaluasi pengaruh desain rumah Niang dalam merespon kondisi termal di dataran tinggi dan menganalisis perilaku material dari elemen desain yang berpengaruh terhadap kinerja termal rumah Niang.

\section{Kajian Pustaka}

Karakteristik iklim pada permukaan bumi akan berbeda dari suatu tempat dengan tempat lain, faktor yang berperan menentukan perbedaan iklim antar wilayah di muka bumi adalah posisi relatif terhadap garis edar matahari, keberadaan laut, dan pola angin (Lakitan, 2002). Variasi suhu tergantung pada ketinggian suatu tempat (altitude), dimana suhu udara akan semakin rendah seiring dengan semakin tingginya ketinggian suatu tempat dari permukaan laut. Setiap kenaikan altitude 100 meter akan menyebabkan perubahan iklim dimana temperatur akan turun $1{ }^{\circ} \mathrm{C}$ pada kondisi udara kering dan tidak jenuh (Evans, 1980).

Kondisi termal pada bangunan dipengaruhi oleh kondisi iklim dan ditentukan oleh kinerja termal dari bangunan. Kondisi termal tersebut disebabkan oleh adanya perpindahan aliran panas antara bangunan dan lingkungannya. Perpindahan panas antara bangunan dan lingkungannya dipengaruhi oleh modifikasi dari 
material selubung bangunan yang akan menentukan temperatur dalam bangunan.

Menurut Givoni (1998) pertukaran panas antara bangunan dan lingkungannya dapat berlangsung dan terjadi melalui proses perpindahan panas secara konduksi, konveksi dan radiasi. Proses perpindahan panas secara konduksi adalah proses perpindahan panas dari molekul yang panas ke molekul yang dingin melalui zat padat. Kecepatan perpindahan panas secara konduksi tergantung pada nilai konduktifitas dari material serta ketebalan elemen selubung bangunan. Konveksi adalah proses perpindahan panas oleh gas dan air (zat fluida) yang disebabkan oleh perbedaan temperatur dan pergerakan udara secara paksa. Radiasi adalah proses perpindahan panas antara permukaan melalui gelombang elektomagnetik yang melalui udara.

Dalam proses pertukaran/ perpindahan panas yang terjadi akan melibatkan perolehan panas dan pelepasan panas yang berlangsung melalui selubung bangunan dengan cara yang berbedabeda (konduksi, konveksi, radiasi) tergantung pada thermophysical properties dan material dari selubung bangunan (Givoni, 1998). Penggunaan bahan atau material yang mempunyai tahan panas yang besar, dapat mengurangi panas karena laju aliran panas yang menembus bahan tersebut menjadi terhambat. Pada bidang bangunan yang terbayangi, panas yang masuk kedalam ruang hanya terjadi melalui proses konduksi saja karena adanya perbedaan suhu luar dan suhu di dalam. Akan tetapi pada bidang bangunan yang terkena sinar matahari (tidak terkena bayangan), maka panas yang masuk kedalam ruang dapat melalui proses radiasi akibat dari radiasi balik dari panasnya dinding yang terkena sinar matahari (Sukawi, 2010).

Bangunan dapat memodifikasi kondisi lingkungan termal menjadi kondisi yang nyaman ataupun tidak nyaman melalui penempatan desain (bentuk bangunan), orientasi bangunan dan melalui penggunaan material dari elemen-elemen bangunan seperti, atap, dinding dan lantai yang sesuai. Untuk daerah dataran tinggi, orientasi bangunan yang tepat adalah arah UtaraSelatan dan bentuk bangunan harusnya compact atau double layer. Bangunan yang berbentuk compact atau double layer dapat membantu memperlambat panas bangunan terhadap kondisi termal (Evans, 1980).

Elemen bangunan seperti atap, dinding dan lantai juga dapat memodifikasi temperatur ruang dalam dengan cara pemilihan material yang sesuai sehingga memungkinkan untuk mendapatkan temperatur ruang dalam yang nyaman. Prinsip dari material bangunan di dataran tinggi adalah yang bisa menyimpan dan menahan panas dan memiliki time lag yang panjang dengan kapasitas termal yang tinggi, agar peningkatan panas yang terjadi pada siang hari dapat dimanfaatkan untuk kenyamanan pada malam hari (Evans, 1980).

\section{Metode Penelitian}

Penelitian dilakukan dalam dua tahap. Tahap pertama adalah studi lapangan (observasi) dan tahap kedua adalah simulasi dengan menggunakan software ARCHIPAK versi 5.0. 


\section{Studi Lapangan}

Tujuan tahapan ini adalah untuk mengetahui kondisi termal rumah Niang yang sesungguhnya, memperoleh gambaran tipologi dan varian bangunan dan mendapatkan data-data kuantitatif berupa data bangunan seperti orientasi bangunan, dimensi bangunan dan elemen-elemen bangunan serta data-data iklim 5 tahun terakhir (2009-2013) dari Stasiun Klimatologi.

Pengukuran kondisi termal dilakukan di dalam dan luar bangunan (selama tiga hari) pada saat yang sama. Pengukuran kondisi termal meliputi temperatur udara, kelembaban udara menggunakan alat Thermohygrometer, yang direkam selama 24 jam. Pengukuran kecepatan angin menggunakan Anemometer yang dilakukan setiap jam mulai dari pkl.06.00 sampai pkl.18.00. Pengukuran radiasi matahari menggunakan Solar Power Meter yang dilakukan setiap jam mulai dari pk1.06.00 sampai pkl.18.00.

\section{Simulasi}

Program simulasi yang digunakan adalah software ARCHIPAK versi 5.0. dengan analisis Harmon dan Elemental Breakdown. Simulasi dilakukan untuk membantu memprediksi kondisi termal rumah Niang pada bulan terdingin dan bulan terpanas serta mengetahui perilaku material dari elemen-elemen desain terhadap kinerja termal rumah Niang dalam merespon kondisi termal di dataran tinggi.

Tujuan simulasi pada bulan terdingin dan terpanas adalah untuk memberikan gambaran bagaimana respon bangunan terhadap potensi iklim ekstrim yang terjadi dalam satu tahun.

\section{Model Simulasi}

Dalam penelitian ini digunakan 2 model tipologi dan varian dari rumah Niang yang sudah dihasilkan berdasarkan pengamatan lapangan di lokasi penelitian.

\section{a. Rumah Model 1}

Lokasi di Desa Todo (800 m dpl), orientasi pintu rumah ke arah Utara. Bentuk denah adalah lingkaran, dengan diameter $20 \mathrm{~m}$ x 20m. Dinding hanya terdapat di bagian depan pintu masuk. Tidak memiliki jendela, hanya sebuah pintu pada bagian depan dengan tinggi $160 \mathrm{~cm}$, lebar $106 \mathrm{~cm}$ dan tebal 0,6 cm.

Atap berbentuk kerucut, menggunakan konstruksi kayu dan bambu dengan ketinggian $22 \mathrm{~m}$ dari permukaan tanah. Atap dari bahan ijuk dengan ketebalan $5 \mathrm{~cm}$. Lantai dari papan kayu yang berukuran lebar dan tebal $25 \mathrm{~cm}$ x 2 $\mathrm{cm}$. Bagian bawah menggunakan konstruksi panggung tanpa pondasi dengan kolom tertanam di dalam tanah.

\section{b. Rumah Model 2}

Lokasi di Ruteng Pu'u (1200 m dpl), orientasi pintu rumah ke arah Selatan. Denah berbentuk lingkaran (membentuk segi 12) dengan diameter $11 \mathrm{~m}$ $\mathrm{x} 11 \mathrm{~m}$. Dinding dari papan setinggi 2,65 m. Di sekeliling dinding terdapat jendela berjumlah 18 buah dan 2 buah pintu (depan dan belakang). Ukuran pintu $1,80 \mathrm{~m} \times 0,90$. Tinggi jendela 1,20 m dan lebar 0,65 m. Semua pintu dan jendela terbuat dari papan kayu, berwarna cokelat tua.

Ruang tengah dengan ukuran $11 \mathrm{~m}$ x 6 $\mathrm{m}$ dan dikelilingi oleh 4 buah kamar tidur. Ukuran kamar tidur $5 \mathrm{~m}$ x 2,5 m. Atap berbentuk kerucut terdiri atas dua belas sisi, sesuai bentuk denah dengan ketinggian mencapai $6 \mathrm{~m}$. Atap dari bahan ijuk dengan ketebalan $5 \mathrm{~cm}$. Lantai dari papan kayu, lebar 22,5 cm 
dan tebal $2 \mathrm{~cm}$. Menggunakan konstruksi panggung tanpa pondasi, kolom diletakkan di atas coran semen.

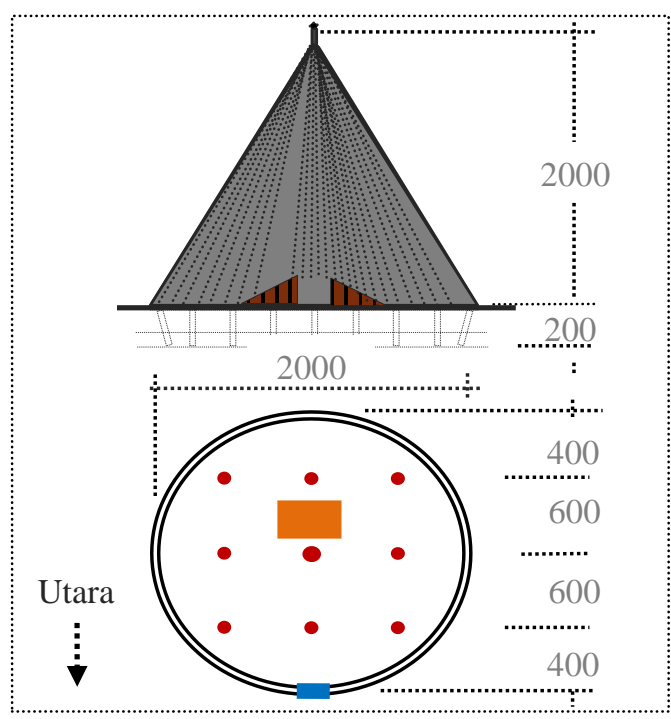

Gambar 1. Denah dan tampak model 1 Sumber: Hasil survei, 2015

Tabel 1. Karakteristik rumah model 1

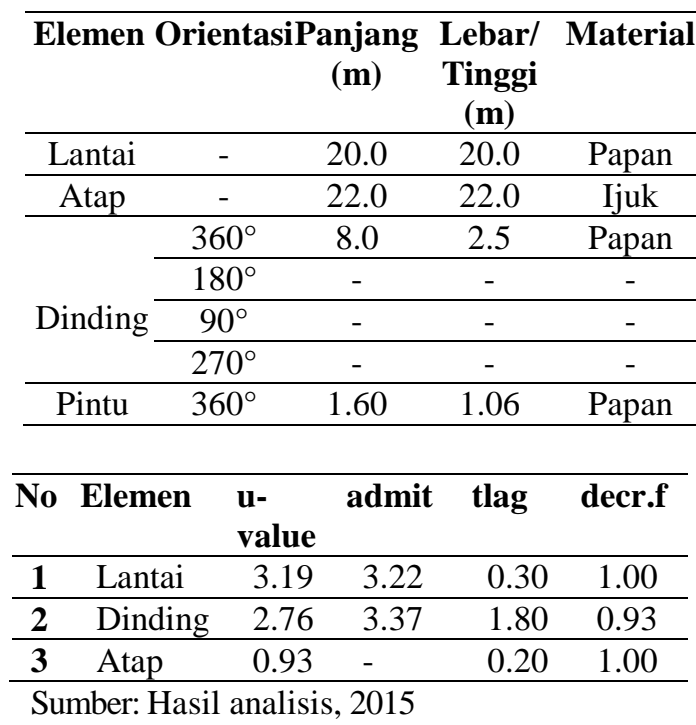

\section{Hasil dan Pembahasan}

\section{Hasil Pengukuran Lapangan}

Dari data pengukuran lapangan selama 3 hari, kondisi termal secara keseluruhan tergolong sejuk dan memiliki pola yang hampir sama. Temperatur udara (To) tergolong rendah hingga sedang yaitu berkisar antara $15^{\circ} \mathrm{C}$ hingga $27^{\circ} \mathrm{C}$, dengan kelembaban udara (RHo) berkisar $48 \%$ hingga $99 \%$.

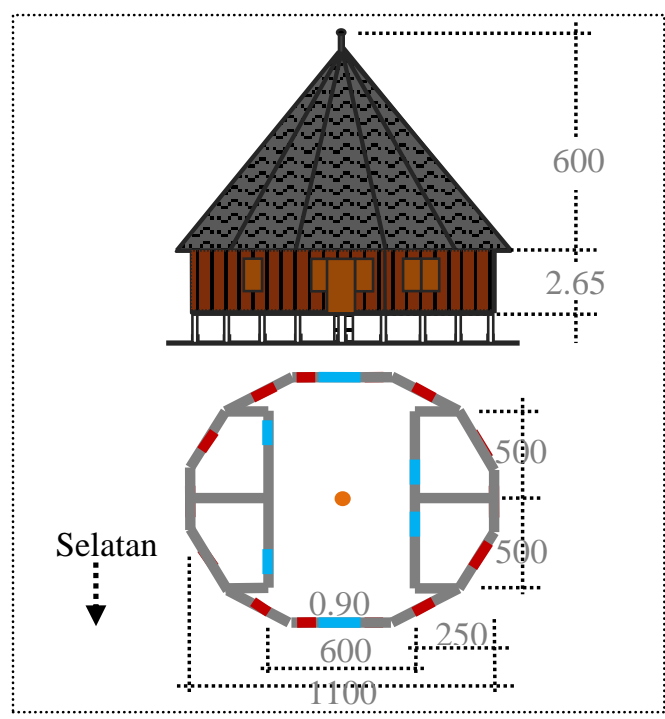

Gambar 2. Denah dan tampak model 2 Sumber: Hasil survei, 2015

Tabel 2. Karakteristik rumah model 2

\begin{tabular}{lcccc}
\hline Elemen Orientasi Panjang Lebar/ Material \\
& & $\begin{array}{c}\text { (m) } \\
\text { Tinggi } \\
\text { (m) }\end{array}$ & \\
\hline Lantai & - & 11.0 & 11.0 & Papan \\
\hline Atap & - & 13.0 & 6.0 & Ijuk \\
\hline \multirow{4}{*}{ Dinding } & $360^{\circ}$ & 5.3 & 2.7 & \\
\cline { 2 - 4 } & $180^{\circ}$ & 6.8 & 2.7 & Papan \\
\cline { 2 - 4 } & $90^{\circ}$ & 5.3 & 2.7 & \\
\cline { 2 - 4 } Jendela & $270^{\circ}$ & 5.3 & 2.7 & \\
\cline { 2 - 4 } & $360^{\circ}$ & 4.8 & 1.6 & \multirow{2}{*}{ Papan } \\
\cline { 2 - 4 } & $180^{\circ}$ & 2.4 & 1.6 & \\
\cline { 2 - 4 } & $90^{\circ}$ & 7.2 & 0.7 & \\
\cline { 2 - 4 } & $270^{\circ}$ & 7.2 & 0.7 & \\
\hline
\end{tabular}

\begin{tabular}{llllll}
\hline No & Elemen & $\begin{array}{l}\text { u- } \\
\text { value }\end{array}$ & admit & tlag & decr.f \\
\hline $\mathbf{1}$ & Lantai & 3.19 & 3.22 & 0.30 & 1.00 \\
\hline $\mathbf{2}$ & Dinding & 2.76 & 3.37 & 1.80 & 0.93 \\
\hline $\mathbf{3}$ & Atap & 0.93 & - & 0.20 & 1.00 \\
\hline \multicolumn{5}{l}{ Sumber: Hasil analisis, 2015} \\
\end{tabular}

Temperatur maksimum (To max) terjadi mulai pukul 10:00 hingga 14:00 dan temperatur minimum (To min) terjadi pukul 06:00. Kelembaban maksimum sering terjadi pada malam hari hingga menjelang pagi hari. 
Kecepatan angin rendah berkisar antara $0,0 \mathrm{~m} / \mathrm{s}$ hingga $7,0 \mathrm{~m} / \mathrm{s}$ dengan dominan arah hembusan angin dari arah Utara dan Timur. Kondisi langit selalu berubah-ubah. Kondisi cerah sering terjadi pada pagi hari, mulai pukul 06:00 hingga pukul 10:00. Kondisi berawan terjadi pada siang hari, mulai pukul 11:00 hingga pukul 14:00 dan kondisi mendung pada sore hari pukul 15:00 hingga pukul 18:00.

Intensitas radiasi matahari cukup tinggi, dengan nilai Irradiation mencapai $1209 \mathrm{~W} / \mathrm{m} 2$. Intensitas radiasi matahari tinggi mulai terjadi pada pukul 10:00 hingga pukul 14:00. Saat intensitas radiasi matahari tinggi, kondisi langit berawan dan ketika intensitas rendah, kondisi langit cerah dan mendung.

\section{a. Rumah Model 1}

Pengukuran dirumah Model 1, Ti max terjadi pukul 13:00 hingga pukul 14:00 yang mencapai $21,2^{\circ} \mathrm{C}$ dan $\mathrm{Ti}$ min mencapai $18,5^{\circ} \mathrm{C}$, terjadi pada pukul 05:00. Kelembaban maksimum (RHi max) terjadi pukul 08:00 yang mencapai $87 \%$ dan kelembaban minimum (RHi min) mencapai $76 \%$ yang terjadi pada pukul 22:00 hingga pukul 23:00. Ketika temperatur mencapai maksimum, perbedaan temperatur ruang luar (To) dan temperatur ruang dalam (Ti) mencapai $1,5^{\circ} \mathrm{C}$, yang terjadi pada pukul $12: 00$ dan ketika temperatur minimum, perbedaannya mencapai $0,9 \mathrm{C}$ yang terjadi pada pukul 06:00.

\section{b. Rumah Model 2}

Pada pengukuran rumah Model 2, Ti max mencapai $23,5^{\circ} \mathrm{C}$ yang terjadi pukul 14:00 dan $\mathrm{Ti}$ min mencapai $17^{\circ} \mathrm{C}$, terjadi pada pukul 06:00. Kelembaban maksimum (RHi) terjadi pukul 07:00 mencapai $83 \%$ dan kelembaban minimum (RHi) mencapai
63\% terjadi pukul 11:00 hingga pukul 12:00. Ketika temperatur mencapai maksimum, perbedaan antara temperatur ruang luar (To) dan temperatur ruang dalam (Ti) mencapai 2,6C yang terjadi pada pukul 10:00 dan ketika temperatur minimum, perbedaannya mencapai 1,3C yang terjadi pada pukul 06:00.

\section{Penentuan Waktu Simulasi}

Dari data iklim kabupaten Manggarai selama rentang waktu 5 tahun terakhir (2009 - 2013), diketahui bahwa bulan terdingin terjadi di bulan Agustus dan bulan terpanas di bulan November.

Kondisi iklim pada bulan Agustus adalah sebagai berikut: temperatur ratarata $18.5^{\circ} \mathrm{C}$, kelembaban rata-rata $77 \%$, curah hujan $44 \mathrm{~mm}$, kecepatan angin $3,4 \mathrm{~m} / \mathrm{s}$ dan radiasi rata-rata 2534 $\mathrm{wh} / \mathrm{m}^{2}$. Kondisi iklim pada bulan November adalah sebagai berikut: temperatur rata-rata $21^{\circ} \mathrm{C}$, kelembaban rata-rata $85 \%$, radiasi rata-rata 2534 $\mathrm{wh} / \mathrm{m}^{2}$, kecepatan angin $2,8 \mathrm{~m} / \mathrm{s}$, curah hujan $450 \mathrm{~mm}$.

Tabel 3. Profil Temperatur Luar (To)

\begin{tabular}{llcc}
\hline No & \multirow{2}{*}{ Keterangan } & \multicolumn{2}{c}{ Bulan } \\
\cline { 3 - 4 } & & Agustus & November \\
\hline 1 & Rata-Rata & $18.8^{\circ} \mathrm{C}$ & $20.8^{\circ} \mathrm{C}$ \\
\hline 2 & Netral & $23.4^{\circ} \mathrm{C}$ & $24^{\circ} \mathrm{C}$ \\
\hline 3 & Batas Bawah & $20.9^{\circ} \mathrm{C}$ & $21.5^{\circ} \mathrm{C}$ \\
\hline 4 & Batas Atas & $25.9^{\circ} \mathrm{C}$ & $26.5^{\circ} \mathrm{C}$ \\
\hline 5 & K-Hours & -79 & -47.2 \\
& UnderHeating & & \\
\hline 6 & $\begin{array}{l}\text { K-Hours } \\
\text { OverHeating }\end{array}$ & - & - \\
\hline Sumber: Analisis simulasi ARCHIPAK $v .5 .0$
\end{tabular}

Verifikasi Data Iklim Hasil Pengukuran dan Simulasi

Verifikasi dilakukan untuk melihat gambaran sejauh mana kesesuain temperatur hasil pengukuran lapangan dengan hasil simulasi. Proses verifikasi dilakukan dengan cara sebagai berikut: 
- Membandingkan temperatur udara luar (To) hasil pengukuran lapangan dengan temperatur udara (To) dari data iklim BMKG 5 tahun.

- Membandingkan temperatur udara dalam ruang (Ti) hasil pengukuran lapangan dengan temperatur udara dalam ruang (Ti) hasil simulasi berdasarkan data iklim BMKG 5 tahun.

Temperatur luar rata-rata di lapangan mencapai $19,8^{\circ} \mathrm{C}$ sementara temperatur luar rata-rata dari $\mathrm{BMKG} 5$ tahun mencapai $20,1^{\circ} \mathrm{C}$. Temperatur udara luar rata-rata dari $\mathrm{BMKG}$ memiliki nilai yang lebih besar dari hasil pengukuran lapangan dengan selisih rata-rata $0,3 \mathrm{~K}$. Selisih terbesar terjadi pada pagi hari (pukul 08:00 - 10:00) mencapai 3,3K. Namun pada sore hari temperatur luar dari hasil pengukuran lapangan cenderung lebih rendah. Hal ini disebabkan oleh kondisi langit pada saat pengukuran cenderung mendung.

\section{Model 1}

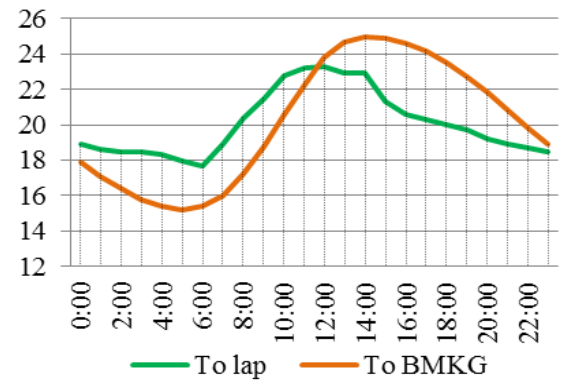

\section{Model 2}

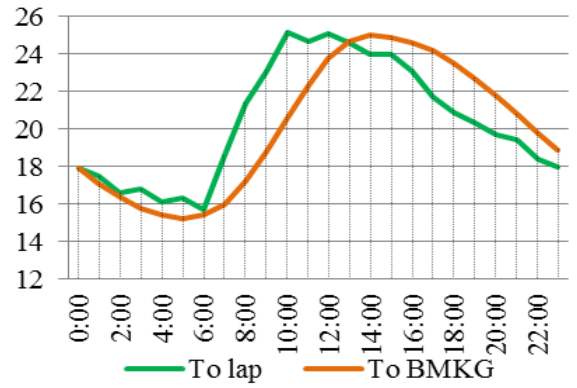

Gambar 3. Perbandingan data temperatur BMKG dan hasil lapangan

Sumber: Hasil analisis, 2015
Profil temperatur luar (To) dari BMKG 5 tahun dengan hasil pengukuran lapangan yang cenderung hampir sama dengan standar deviasi (Sdev) sebesar 3,35. Verifikasi data Temperatur luar (To) dari BMKG 5 tahun dengan To hasil pengukuran lapangan melaui uji-t menghasilkan nilai $t=0,362$. Hasil tersebut berada pada daerah penerimaan $-2,02$ dan $+2,02$. Sehingga data temperatur luar (To) BMKG dapat digunakan untuk merepresentasikan kondisi To yang sesungguhnya dilapangan dengan tingkat kesalahan yang relatif kecil.

Hasil verifikasi kondisi Ti lapangan dengan Ti simulasi menggunakan data BMKG 5 tahun yang dilakukan melalui uji-t diketahui bahwa kedua model rumah Niang tersebut berada dalam area penerimaan $-2,02$ dan $+2,02$.

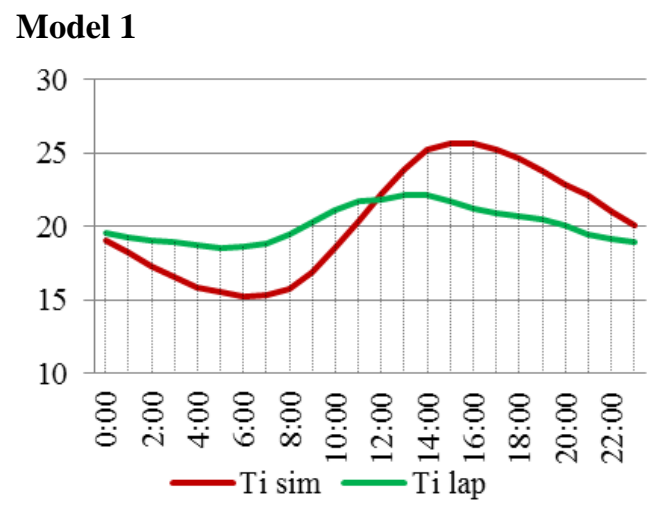

Model 2

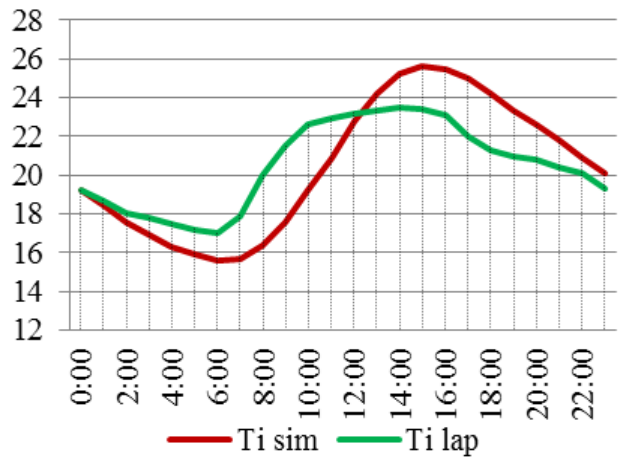

Gambar 4. Verifikasi data BMKG 5 tahun dengan data lapangan

Sumber: Hasil analisis, 2015 
Keterangan

Model 1:

- Sdev $: 2,75$

- $\mathrm{t}$ : 0,408

- di dalam area penerimaan -2,02 dan $+2,02$

- Ti simulasi : $20,3^{\circ} \mathrm{C}$

- Ti lapangan : $20,1^{\circ} \mathrm{C}$

\section{Model 2:}

- Sdev

- $\mathrm{t}$ : 0,484

- di dalam area penerimaan -2,02 dan $+2,02$

- Ti simulasi $: 20,5^{\circ} \mathrm{C}$

- Ti lapangan : $20,5^{\circ} \mathrm{C}$

\section{Kondisi Termal Model Simulasi}

a. Kondisi Termal Bulan Terdingin

Simulasi model 1, rata-rata temperatur luar (To) adalah $18,8^{\circ} \mathrm{C}$ dan rata-rata temperatur dalam (Ti) $19,1^{\circ} \mathrm{C}$ dengan perbedaan diurnal antara To dan $\mathrm{Ti}$ 0,3K. Kondisi termal rumah model 1 mengalami underheating $(75,4 \mathrm{Kh})$ pada pukul 22:00-11:00 dan kondisi overheating $(0,3 \mathrm{Kh})$ pada pukul 15:0016:00. Kondisi nyaman pada pukul 12:00-14:00 dan pukul 17:00-21:00.

Simulasi model 2 , rata-rata $\mathrm{Ti} 19,2^{\circ} \mathrm{C}$ dengan perbedaan diurnal $0,4 \mathrm{~K}$. Kondisi termal rumah model 2 mengalami underheating pada malam hari hingga pagi hari pukul 21:0011:00 dengan jumlah heating $K$-hours sebesar 69,6Kh. Kondisi overheating $(0,1 \mathrm{Kh})$ pada pukul 15:00 dan kondisi nyaman pada pukul 12:00-14:00 dan pukul 16:00-20:00.

Hasil simulasi di bulan terdingin (Agustus), kondisi temperatur luar (To) dan temperatur dalam (Ti) cenderung tidak berbeda jauh.

Temperatur luar (To) cenderung menurun pada pukul 16:00 hingga pukul 06:00. Ketika Temperatur menurun kondisi $\mathrm{Ti}$ berada diatas To dan ketika temperatur cenderung mulai naik pada pukul 07:00 hingga pukul 15:00, kondisi To berada diatas Ti.

Kondisi underheating pada rumah model 1 lebih pendek satu jam yaitu 14 jam dibandingkan rumah model 2 dengan durasi 15 jam dan kondisi overheating di rumah model 1 lebih panjang dengan durasi 2 jam dibandingkan rumah model 2 yaitu hanya 1 jam. Untuk durasi nyaman didalam bangunan selama periode 24 jam baik rumah model 1 maupun rumah model 2 sama-sama memiliki durasi 8 jam.

Zona nyaman yang ditentukan berdasarkan persamaan yang dikemukakan oleh Auliciems (1981) yaitu $\mathrm{Tn}=0,31+17,6 \mathrm{x}$ To, dengan rentang kenyamanan $+/-2.5 \mathrm{~K}$ diatas dan dibawah temperatur netral (Tn) yaitu $21^{\circ} \mathrm{C}-26^{\circ} \mathrm{C}$ (Tbw: batas bawah, Tat: batas atas).

\section{b. Kondisi Termal Bulan Terpanas}

Simulasi model 1 , rata-rata To $20,8^{\circ} \mathrm{C}$ dan rata-rata $\mathrm{Ti} 20,9^{\circ} \mathrm{C}$ dengan perbedaan diurnal $0,2 \mathrm{~K}$. Kondisi di dalam rumah model 1 mengalami underheating pada pukul 23:00 hingga pukul 11:00 dan kondisi nyaman mulai pukul 12:00-22:00 lebih panjang dibandingkan di bulan terdingin dan tanpa ada jeda waktu karena tidak mengalami kondisi overheating seperti yang terjadi di bulan terdingin dan jumlah heating $K$-hours pada bulan terpanas sebesar $46,4 \mathrm{Kh}$.

Kondisi underheating pada model 2 terjadi pada pukul 23:00-11:00 lebih pendek 2 jam dari kondisi underheating di bulan terdingin dan kondisi nyaman terjadi pada pukul 12:00-22:00 lebih panjang 2 jam 
dibandingkan di bulan terdingin. Perbedaan diurnal antara temperatur minimum $\mathrm{Ti}$ dengan batas bawah temperatur nyaman berkisar antara $0,2 \mathrm{~K}$ hingga $5,2 \mathrm{~K}\left(16,3^{\circ} \mathrm{C}-21,3^{\circ} \mathrm{C}\right)$. To maksimun terjadi pada pukul 14:00 $\left(25,7^{\circ} \mathrm{C}\right)$ dan Ti maksimum pada pukul 15:00 $\left(26,3^{\circ} \mathrm{C}\right)$.

Perbedaan diurnal antara temperatur maksimum $\mathrm{Ti}$ dengan batas atas temperatur nyaman adalah $0,2 \mathrm{~K}$ dan untuk kebutuhan pemanasan (heating K-hours) sebesar 41Kh.

Hasil simulasi di bulan terpanas (November) terjadi peningkatan durasi nyaman sehingga durasi underheating mengalami pengurangan. Kondisi nyaman di bulan terpanas baik rumah model 1 maupun rumah model 2 pada umumnya terjadi pada pukul 12:00 hingga pukul 22:00 dengan durasi 11 jam lebih panjang dibandingkan di bulan terdingin yaitu 8 jam dan samasama mengalami kondisi underheating selama 13 jam.
Jumlah heating K-hours (panas yang dibutuhkan) di bulan terdingin maupun dibulan terpanas, pada rumah model 1 $(75,4 \mathrm{Kh}$ dan $46,4 \mathrm{Kh})$ lebih besar dibandingkan rumah model $2(69,6 \mathrm{Kh}$ dan $41 \mathrm{Kh})$ dengan selisih perbedaan $5,8 \mathrm{Kh}$ di bulan terdingin dan $5,4 \mathrm{Kh}$ di bulan terpanas.

Kebutuhan panas yang besar pada rumah model 1 dipengaruhi oleh volume ruang yang lebih besar (surface to volume ratio) serta berbentuk singel layer (tidak adanya sekat ruang) sehingga tidak dapat membantu memperlambat panas keluar dari bangunan.

Rasio dari luas permukaan dan volume merupakan indikator yang penting dari percepatan pemanasan dan pendinginan bangunan (Evans, 1980) dan menurut Woods dan Antaryama (1995), keterbukaan atau tidak adanya penyekat ruang didalam hunian membantu pelepasan panas menjadi lebih mudah.

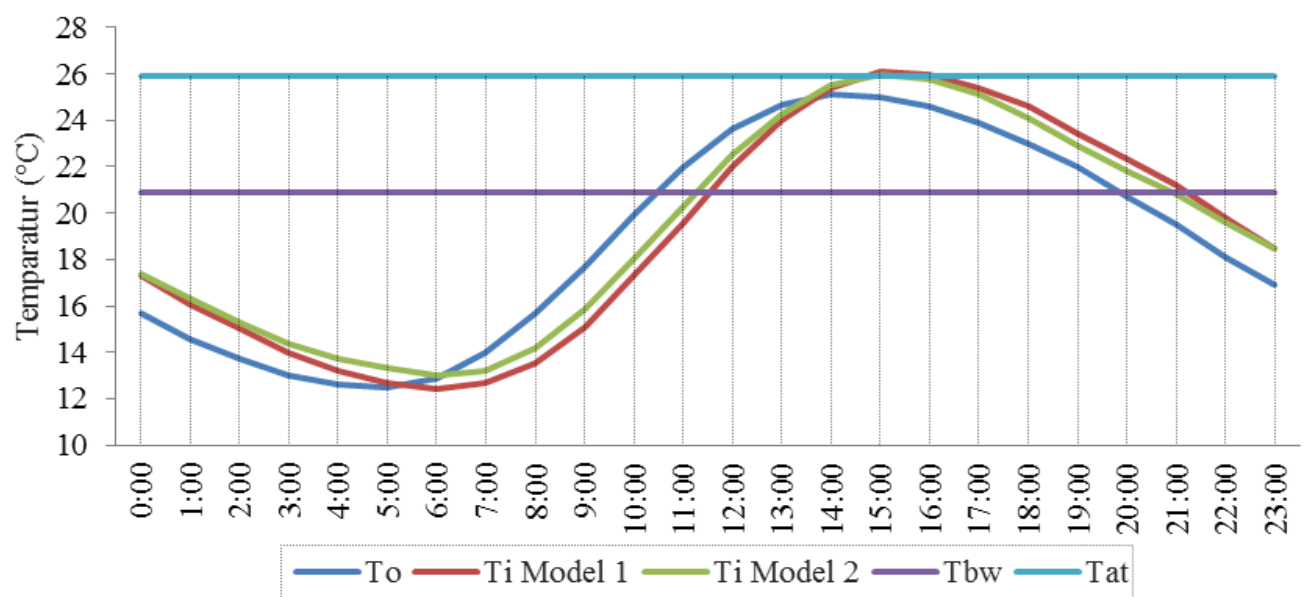

Gambar 5. Kondisi To, Ti Model 1 dan 2 pada bulan terdingin (Agustus)

Sumber: Hasil analisis, 2015 


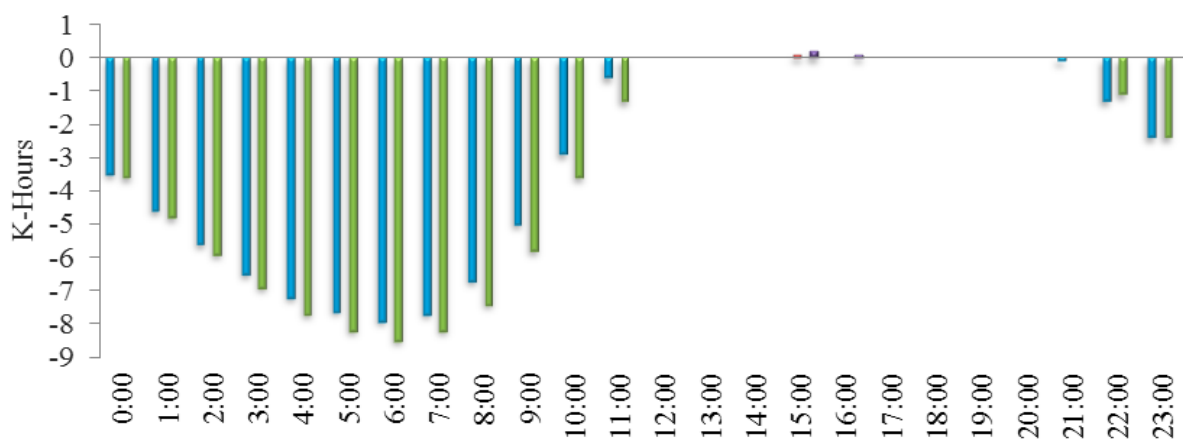

$\begin{array}{lll}\text { Model } 1 \text { Heating-Kh } & \text { Model } 1 \text { Cooling-Kh } \\ \text { Model } 2 \text { Heating-Kh } & \quad & \text { Model } 2 \text { Cooling-Kh }\end{array}$

Gambar 6. Grafik Degree Hours Model 1 dan 2 pada bulan terdingin (Agustus)

Sumber: Hasil analisis, 2015

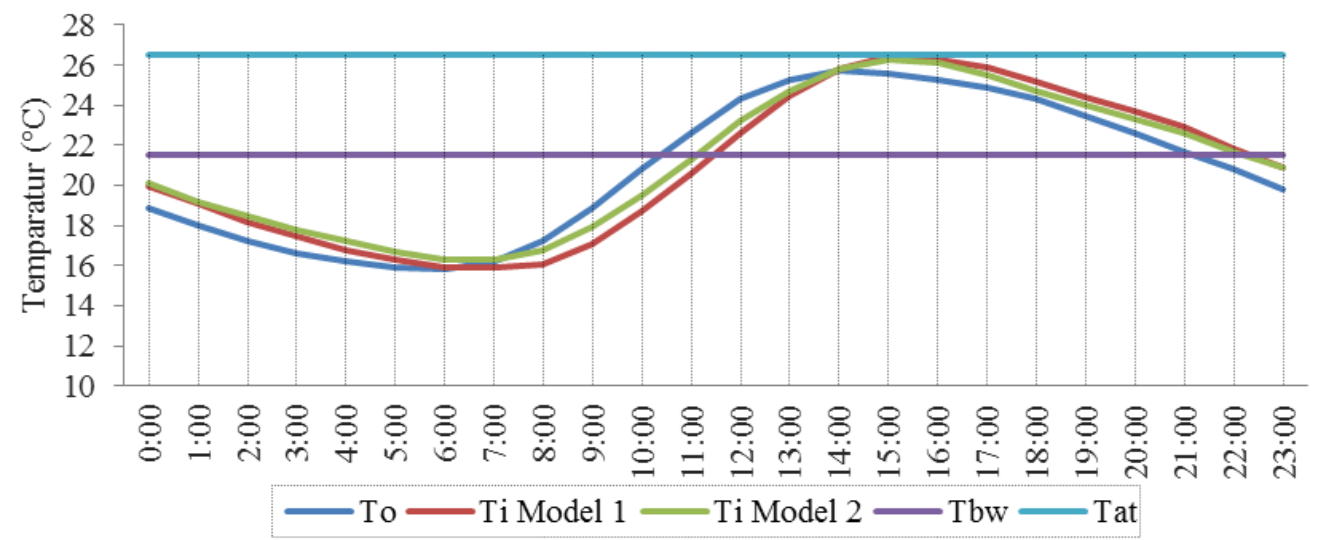

Gambar 7. Kondisi To, Ti Model 1 dan 2 pada bulan Terpanas (November)

Sumber: Hasil analisis, 2015

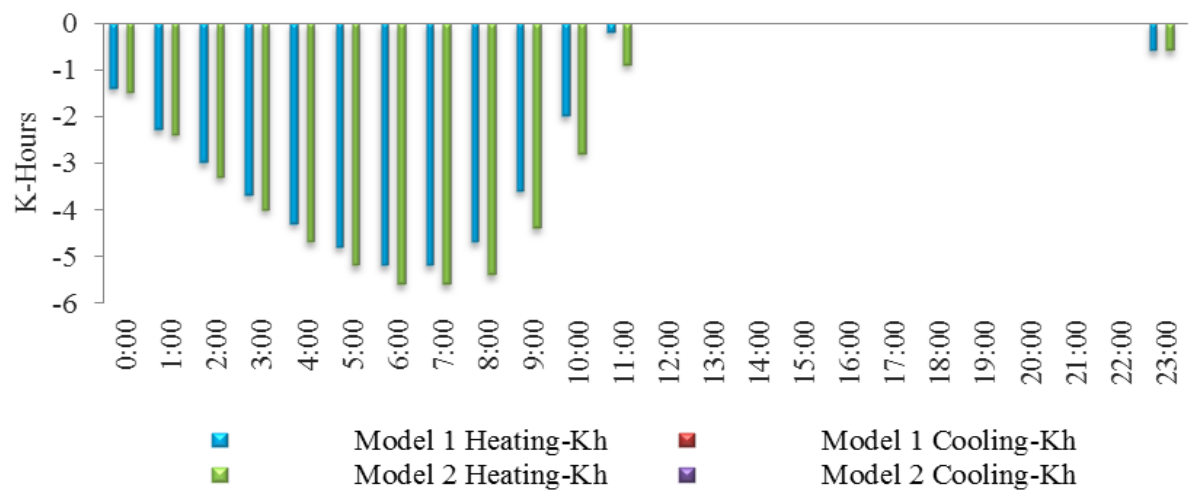

Gambar 8. Grafik Degree Hours Model 1 dan 2 pada bulan terpanas (November) Sumber: Hasil analisis, 2015

\section{Respon Termal Bangunan}

Hasil analisis Elemental Breakdown, lantai dan atap pada rumah model 1 adalah elemen bangunan yang paling kritis dalam pelepasan panas (heat loss) dan pemasokan panas (heat gain) dengan nilai heat flow elemen lantai Qtotal: -323,6 w/h (bulan terdingin) 
dan Qtotal: $-324,9 \quad \mathrm{w} / \mathrm{h}$ (bulan terpanas). Nilai heat flow elemen atap, Qtotal: -154,1 w/h (bulan terdingin) dan Qtotal: $-192,5 \mathrm{w} / \mathrm{h}$ (bulan terpanas).

Pelepasan dan pemasokan panas elemen atap dan lantai pada rumah model 1 mempunyai kontribusi yang lebih besar dibandingkan rumah model 2 , ini disebabkan oleh luas permukaan elemen lantai dan atap rumah model 1 cukup besar sehingga membutuhkan energi panas yang lebih maksimal untuk menciptakan kondisi nyaman dalam bangunan.

Nilai $U$-value dari elemen lantai dan atap tergolong besar $\left(3.20 \mathrm{~W} / \mathrm{m}^{2} \mathrm{~K}\right)$ dan memiliki time lag yang pendek (0.30 jam) sehingga panas yang mengalir melalui kedua elemen tersebut menjadi besar sehingga mempunyai kecenderungan suhu didalam ruang (Ti) tidak jauh berbeda dengan suhu udara diluar (To).

Dinding adalah elemen yang terkecil dalam pelepasan panas dan pemasokan panas. Nilai heat flow untuk dinding rumah model 2 adalah Qtotal: $-13 \mathrm{w} / \mathrm{h}$ (bulan terdingin) dan Qtotal: $-17 \mathrm{w} / \mathrm{h}$ (bulan terpanas) lebih besar dibandingkan rumah model 1 yaitu Qtotal: -4,5 w/h (bulan terdingin) dan Qtotal: -6,8 w/h untuk bulan terpanas.

Nilai heat flow dinding rumah model 1 lebih kecil karena dinding pada rumah model 1 hanya pada satu sisi saja berbeda pada model 2 yang memiliki dinding pada semua sisi.

Nilai heat gain dan heat loss lebih besar terjadi di bulan terdingin (Agustus) dibandingkan di bulan terpanas (November). Heat gain yang besar di bulan Agustus dipengaruhi oleh intensitas matahari yang cukup tinggi, sehingga panas yang dihasilkan kemudian diserap oleh material dan ditransferkan kedalam bangunan. Dan hal yang sama juga terjadi pada prosesnya heat loss, dimana pada bulan tersebut kondisi lingkungannya cenderung lebih dingin sehingga panas yang dihasilkan mudah dilepaskan.

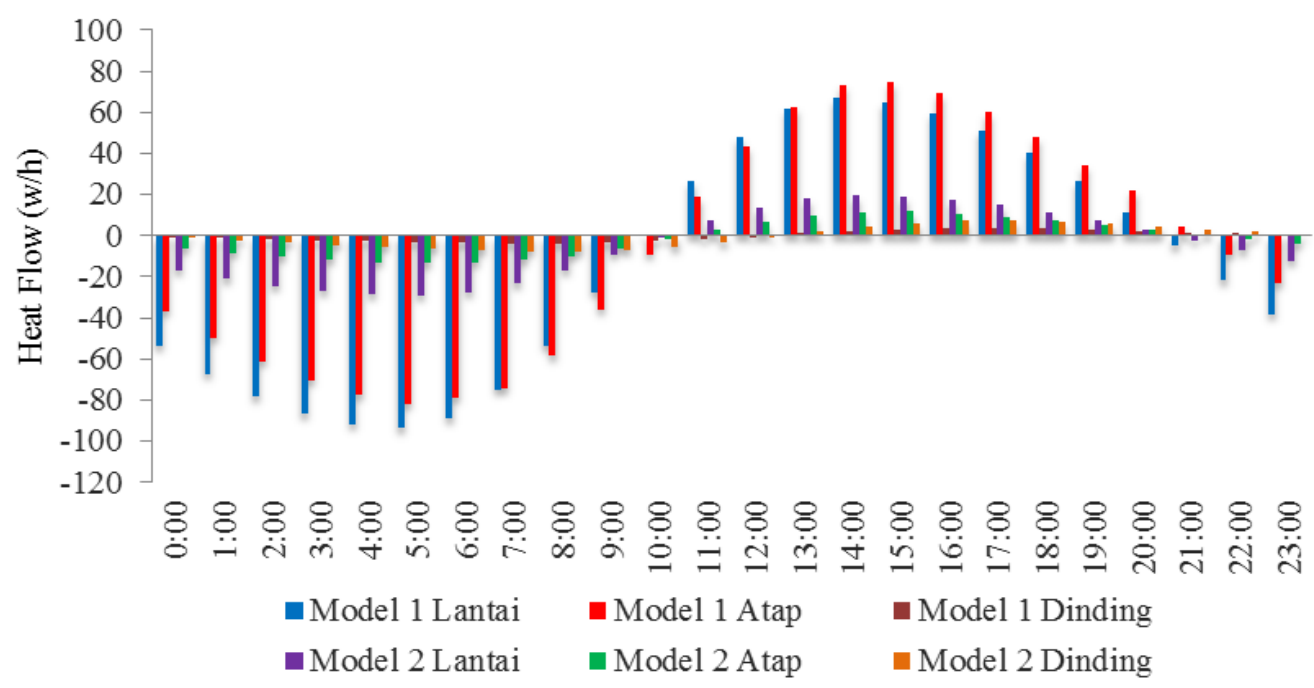

Gambar 9. Elemental Breakdown di bulan terdingin (Agustus)

Sumber: Hasil analisis, 2015 


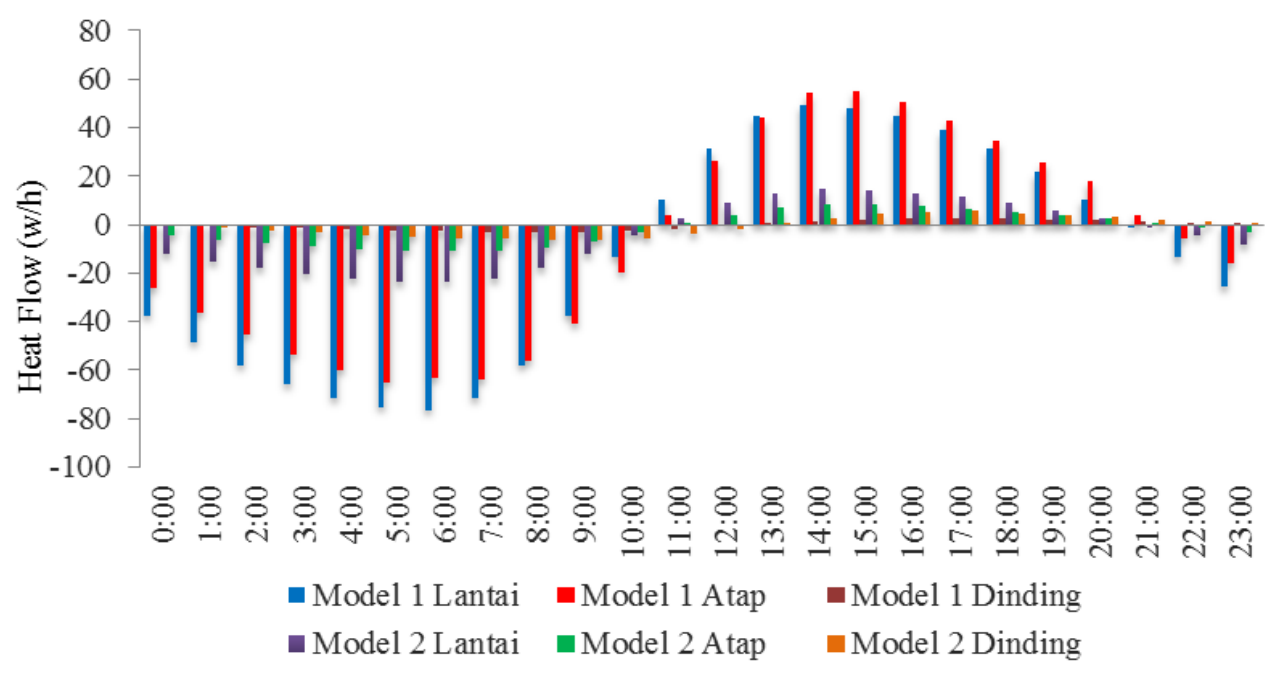

Gambar 10. Elemental Breakdown di bulan terpanas (November)

Sumber: Hasil analisis, 2015

\section{Kesimpulan}

Dari uraian di atas dapat ditarik kesimpulan sebagai berikut:

1. Elemen bangunan belum dapat memberikan kenyamanan termal yang memadai terutama pada malam hingga pagi hari, dimana kondisi bangunan cenderung mengalami underheating dalam periode yang cukup lama.

2. Karakter elemen bangunan lebih cenderung sebagai pelepas panas karena nilai $U$-value tergolong besar dan time lag yang pendek sehingga tidak dapat menahan dan menyimpan panas lebih lama untuk diperlukan pada malam hari ketika lingkungan cenderung dingin.

3. Orientasi bangunan sudah tepat yaitu arah Utara-Selatan namun bentuk bangunan yang singel layer tidak dapat membantu memperlambat panas keluar dari bangunan dan volume bangunan yang cukup besar akan membutuhkan energi panas yang besar untuk menciptakan kondisi nyaman dalam bangunan.

\section{Daftar Pustaka}

Damayanti, D.P. dan Suprijanto, I. (2009). Mbaru Niang Wowang Bangunan Manggarai yang makin terpinggirkan. Riset, Majalah Litbang Kementerian Pekerjaan Umum, Vol. VII, no. 1 (Hal. 24)

Evans, M. (1980). Housing climate and comfort. London: The Architectural Press.

Givoni, B. (1998) Climate considerations in building and urban design. New York: Van Nostrand Reinhold.

Lakitan, B. (2002). Dasar-dasar klimatologi. Cetakan Ke-2. Jakarta: Raja Grafindo Persada.

Lippsmeier, G. (1980). Bangunan tropis. Edisi ke-2. Jakarta: Penerbit Erlangga.

Sukawi (2010). Kaitan desain selubung bangunan terhadap pemakaian energi dalam bangunan: Studi kasus perumahan Graha Padma Semarang. Jurusan Arsitektur Fakultas Teknik Universitas Diponegoro, Semarang (laporan penelitian, tidak dipublikasikan). 